Original Research Paper

\title{
Phytoremediation and Adsorption of Heavy Industry Emitted from Cement Industry through Plant Leaves, Case Study: Golestan Peivand Cement Factory
}

\author{
${ }^{1}$ Soleyman Ghorbanzadeh, ${ }^{2}$ Meysam Madadi, ${ }^{3}$ Sara Abdollahi and ${ }^{4}$ Kaveh Ostad-Ali-Askari \\ ${ }^{1}$ Student of Natural Resources and Environment Engineering, Air Pollution, Islamic Branch, Tonekabon, Iran \\ ${ }^{2}$ Department of Environmental Science, Gorgan University of Agriculture Science and Natural Resources, Gorgan, Iran \\ ${ }^{3}$ Environmental Science, Faculty of Natural Resources and Desert Studies, Yazd University, Yazd, Iran \\ ${ }^{4}$ Department of Water Engineering, College of Agriculture, Isfahan University of Technology, Isfahan 8415683111, Iran
}

\section{Article history}

Received: 22-06-2018

Revised: 21-07-2018

Accepted: 21-11-2020

Corresponding Author: Kaveh Ostad-Ali-Askari Department of Water Engineering, College of Agriculture, Isfahan University of Technology, Isfahan 8415683111, Iran

Email: ostadaliaskari.k@of.iut.ac.ir \&kaveh.oaa2000@gmail.com

\begin{abstract}
Cement factories are found to be one of the major causes of pollution. Cement mist and dusts depositions affect the photosynthesis, secretion and fertility of the plant. Increasing the concentration of airborne dust reduces photosynthetic potential in leaves, closes leaf stomatals and, in general, reduces the growth and fertility of plants. The purpose of this study is to determine the best tree species for absorbing contaminants from the cement plant. Data were analyzed using descriptive statistics and inferential statistics. To determine the normal distribution of metal content in oak, Paliurusspina-christi Phragmitesaustralis, Kolmogorov-Smirnov test was used and one-way analysis of variance was used to determine the difference. The results showed that $\mathrm{F}$ calculated for cadmium level $(F=4.123)$ with degrees of freedom $\mathrm{df}=17$ and $\mathrm{df}=2$ at $95 \%$ confidence level $(\alpha=0.05)$ is greater than $F$ from critical table $(F=3.59)$, therefore difference between cadmium and oak and Paliurusspina-christi and Phragmitesaustralis plants is statistically significant, but the means of other metals in oak and Paliurusspina-christiandPhragmitesaustralisis statistically equal. Also, the amount of cadmium with oak tree was significantly different $(\mathrm{P}$-value $=0.049)$. It was found that the cadmium content of the Paliurusspina-christi was higher than the oak tree, in other words Paliurusspina-christicadmium others get better.
\end{abstract}

Keywords: Air Pollution, Cement Industry, Paliurusspina-christi Golestan

\section{Introduction}

Air pollution is one of the most important environmental problems that have always been a serious threat to public health and health (Perez and Reyes, 2006). Industrialization, urbanization and continuous growth of the population have led to an increase in air pollution and the environment. Chronic exposure to air pollutants is a widespread global problem; (Daryanoosh et al., 2016).

The cement sector is one of the most important sectors producing pollutants in the environment, which has significant environmental effects on the ecosystem. The most important pollutants from the cement industry are the immediate and local effects of particles and carbon monoxide, each of which has a different effect on living organisms and the environment. Abbasi and Salari (2006) Air Pollution Caused by Outputs from the Manufacturing Industries Cement can be considered an important source of environmental pollution. Dust and gases from the cement industry today are of particular importance to manufacturers and pro-environmental organizations and residents around the factories. The presence of particles along with air pollutants such as nitrogen and carbon atoms in the smoke exhaust can have irreparable effects on humans and the environment around the above industries, such as plants (Singh and Rao, 1981). The particles released from the cement 
industry, due to their size and composition with other air pollutants, have various and irreparable effects on plants. However, the existence of abundant mines, favorable energy reserves and the high demand for domestic and foreign markets has led to a dramatic increase in the growth rate of cement industry in recent years. Dust and gases from the cement industry have increased with increasing production and in addition to air pollution, soil contamination and subsequent damage to plant tissues (Environmental Protection Organization, 2003). Increasing the concentration of dust released from cement plants in the air will reduce the photosynthesis potential, close the stomata of the leaves and, in general, reduce the growth and fertility of the plants (Mosavi et al., 2015). Cement dust particles often have a diameter of less than 10 microns and, given that the means diameter of the plant apertures is 30 microns (Majnounian, 1990), these particles easily permeate the middle tissue of the plant and since more than $80 \%$ These particles form calcium carbonate $\left(\mathrm{CaCO}_{3}\right)$, react with inter-tissue water and produce carbonic acid (Farmer, 1993). Iran is one of the few countries that are seriously looking for a widespread expansion of the cement industry, with cement production from 13 thousand tons in 1956 to 1963 million tons in 2007, the highest level of production in the Middle East (Sadeghiravesh and Khorasani, 2009). Studies in Iran have shown that there is a reverse correlation between vegetation density and vegetation density, with dust particles deposited out of factory chimneys. As far as the source of particles is farther away, the amount of deposition of particles decreases and vegetation density and diversity increase. In the vicinity of the plant, the amount of deposition of more particles and species diversity is reduced (Kakooei et al., 2012).

The effect of dust particles on cement plants on communities and ecosystems.

\section{Effect on Human Health}

Persons exposed to cement particles are at risk of developing pulmonary, respiratory and digestive diseases (Adak and Purohit, 2007). Also, those exposed to cement particles released from their workplace are at risk of increased liver abnormalities, pulmonary disorders and cancer. Reducing the antioxidant capacity of blood plasma is a possible cause of the mechanism of the disease (Aydin et al., 2010).

\section{Effect on Plants}

Dust deposits physically affect plants either directly or indirectly and can degrade plant resources. The plant stomata are blocked by the deposition of cement particles on the surface of the leaves and thus the mechanism of air exchange and the use of sunlight (the process of photosynthesis) is disrupted (Migahid and El-Darier, 1995). Particles released from cement factories are often taken to the areas around the factory through wind and settling in the factory. Such deposits of fine particulate matter and other pollutants interfere with the metabolic activities of the plants and cause serious damage to the growth and plant quality and the closure of the leaf aperture, early fall and eventually plant crop decline (Singh and Rao, 1981).

\section{Impact on Surface and Ground Waters}

When particles of cement come into contact with water, hydroxide is formed which eliminates the natural water play and covers a thin layer of cement covering the surface of the springs and lakes. Water hardness, which is subsequently responsible for respiratory and intestinal diseases in the area, is affected by the excess salt of $\mathrm{AL}, \mathrm{Mg}, \mathrm{K}, \mathrm{Na}, \mathrm{Ca}$, such as hydroxides, sulfates and silicates (Mishra, 1991).

Considering the above mentioned issues, which indicates the increasing development of the cement industry in the country and since these industries are potentially polluting the environment, it is necessary to identify the identified effects and appropriate strategies for controlling and decreasing it. The purpose of this study was to investigate the effect of cement dust on leaf of tree species around Golestan cement plant. Therefore, the Neka Cement Plant, with its production of over 3 million tons of Portland cement per year, is considered as the largest cement producer in the country, located near the three villages and forests, to determine the absorption of pollutants from the industry's dust.

Studies on contamination of cement industry in Iran and in the world.

Bertoldi et al. (2012) explored the impact of the cement industry on the health of the population of plants near the cement factory in two cities of Italy and found that this industry has very harmful effects on the health and life of the plant population near the plant. Princewill and Adanma, 2011) studied the concentration of pollutants such as manganese, chromium, cadmium, zinc and iron in woody species Azadiracthaindica, MangiferaindicaAndropogongayanus, Uvareachamaeand Gmelinaarborea around the cement plant in Nigeria. There was a positive and significant correlation between heavy metals in soil and plant growth and the concentration of Cadmium element was higher than standard. Amal and Migahid (2011) in the western part of Egypt on wild spinach desert species and stated that annual species are very sensitive to pollution of cement plants and have less growth than plants in less polluted areas and the amount of chromium has been less pronounced in the one-year-old species. Nanos and llias (2007) in a region called Vlús, the Greek center, 
cement dust on the parameters of the physiology of olive leaves and stated that cement mist changes the leaf physiology, which is the result of a change in plant fertility (Figs. 1 and 2). The research hypothesis can be considered a scientific guess or pre-judgment, which is tested by gathering the facts that leads to acceptance or rejection of that hypothesis. In other words, the hypothesis is considered as the proposed solution by the researcher for the research problem or the result of the research. For this research, a hypothesis is considered. Thus, the absorption of metal elements in tree species is more than shrub species. One of the objectives of this research is to determine the best tree species to absorb pollutants released from the cement plant.

\section{Materials and Methods}

\section{Geographic and Human Features of the Studied Area}

Golestan province with 2.2 million hectares of land, consisting of a total area of Golestan province, is about 1126000 hectares and a forested area is about 430000 hectares and totally accounts for about $70 \%$ of the province's natural resources.

Galicash is one of the cities of Golestan province in northern Iran. The city of Galicash was founded in 2010. The center of the city is its Galicash city. The Golestan Cement Cement Factory is located $6 \mathrm{~km}$ from Galikesh city, located in Golestan province and is located at the foot of the Nile Mountain of the AlborznMountain.

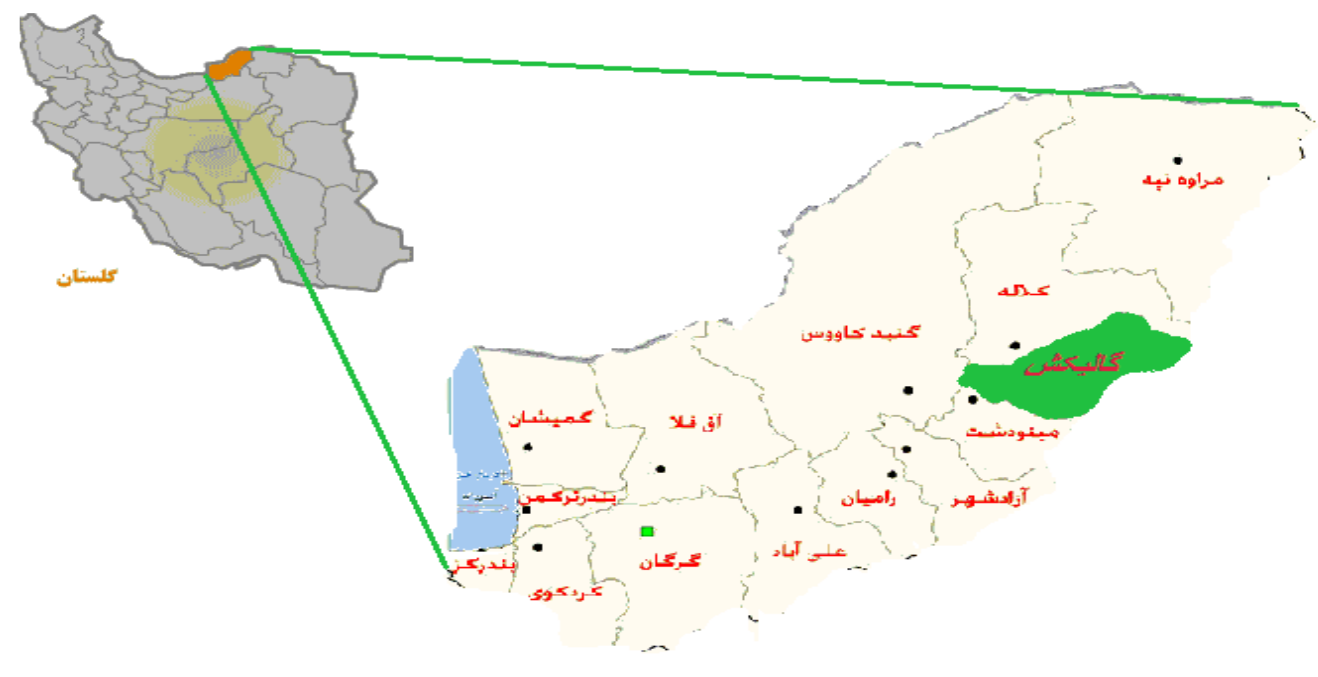

Fig. 1: Geographical location of the studied area

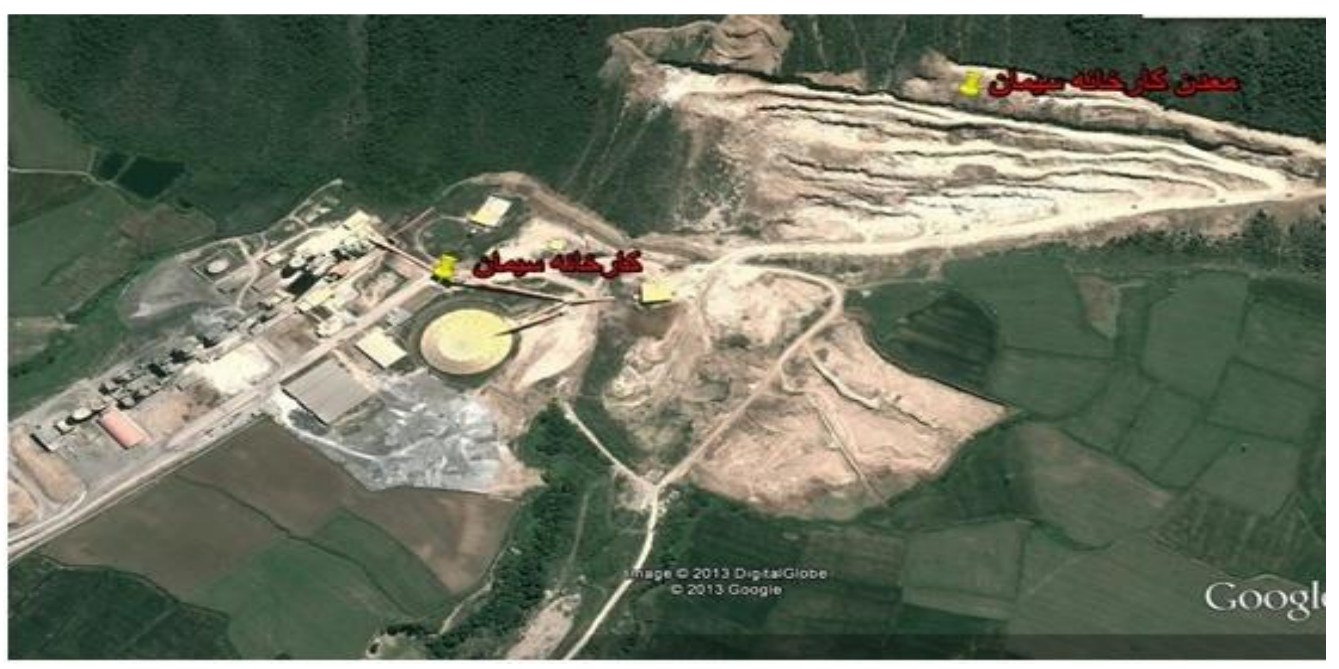

Fig. 2: Cement and mine extraction raw materials 


\section{Research Method}

\section{Determine Sampling Stations}

To do this, seven stations were selected; the first station in the factory and six stations outside the area around the factory were selected. The stations were selected in such a way that there are three species of vegetation studied, including Paliurusspina-christi, oak and Phragmitesaustralis. Each station had three replications and for each sample of Paliurusspina-christi leaf, oak and Phragmitesaustralis, 21 samples were collected from all over the region.

\section{How to do Sampling}

Sampling was carried out at the specified points in July. At first, after examining the area and identifying species, among the species in the factory, three species were distributed at almost all levels of the factory and the surrounding area. Species were Quercus, Paliurusspina and Phragmitesaustralis. The sampling time has been in the period of growth and before the leaf fall, when it has the highest accumulation of contamination. Then she began to prepare leaf samples from the three species mentioned from the factory. Sampling was performed on sunny days (at least 10 days intervals from the last rainfall). The leaves were collected from the outer surface of the canopy from a height of 1 to $2 \mathrm{~m}$ from the surface of the earth and those facing the factory. To ensure that the leaves are homogeneous, leaflets with a length of $10.5 \mathrm{~cm}$ were collected. At each station, 1 sample tree was sampled. In the selection of stations, the dominant region of the region was of great importance, as it was sampled which was dominant in the direction of the wind and was located behind the factory. The leaves were then placed in plastic protective containers with minimal handling on the plastic and placed on each plastic bag, specifying the specimen type and the station number and repeat. A total of 21 leaf samples were taken (Fig. 3).

\section{Sample Preparation}

In the next step, the leaves dried out in open air and covered in a covered area and lasted for one to two weeks. After removing the samples from the plastic bags, place them on plain paper and exposed to air and then, after drying, the crushing machine is used for crushing the samples. Then they were transferred to the lab and in the laboratory section the digestion was carried out and samples were read by the ICP concentrations of the elements.

\section{Concentration Measurement of Heavy Metals}

\section{Sample Digestion Method (AQU Regia Method)}

In this method, digestion of chloride and nitric acid was used. First, pour $5 \mathrm{~g}$ of the sample into the test tube, then add $5 \mathrm{~cm} \mathrm{HCl}$ of acid and $2 \mathrm{cc}$ of acid nicotine and place it in the binomial for 1.5 to $2 \mathrm{~h}$. After cooling with distilled water, the volume was $20 \mathrm{cc}$ and then the solution was straightened. In the next step, using the ICP device, the concentration of heavy metals was measured (Moopam, 1999).

\section{Sem Electron Microscope Test}

Leaf specimens were subjected to electroscopic microscopic observations for dust morphology studies. In this regard, the Scanning Electron Microscopy (SEM) XL30 model manufactured by the Phillips Corporation of the Netherlands, which was located at TarbiatModarres University, as well as the golden laminating machine used to laminate the samples used in this study, was manufactured by Bal- Tec is from Switzerland.

\section{Information Analysis Method}

The data were normalized using KolmogorovSmirnov test and homogeneity of variances with Levene's test. In the case of data normalization and homogeneity of data variance, one-way ANOVA was used to compare the parameters. Tukey-HSD tests were used to compare the meanss. Pearson test was used to obtain correlation. All statistical tests were performed using SPSS v.11.5 software.

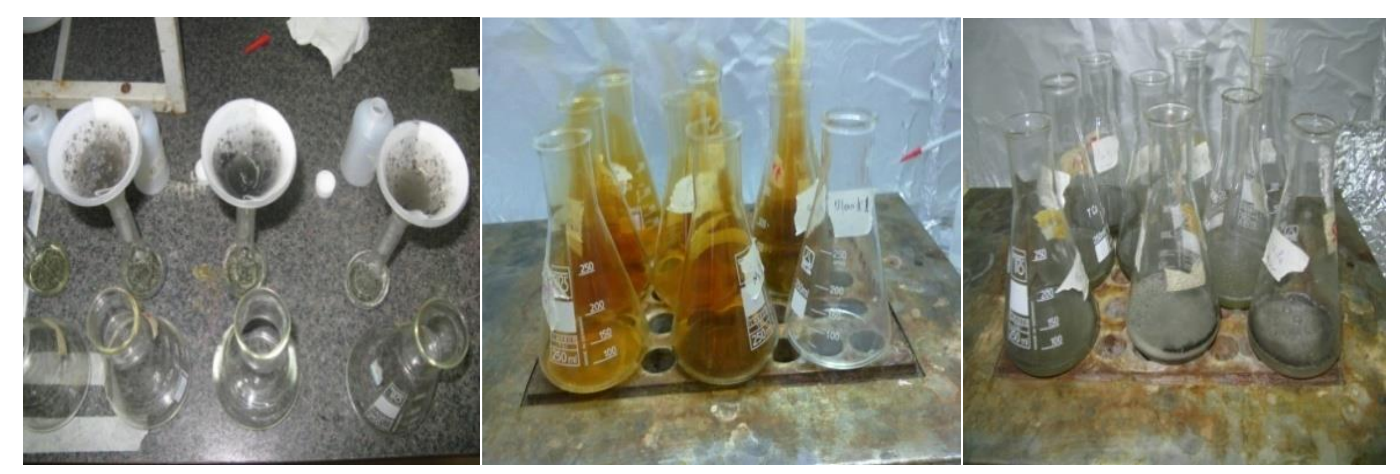

Fig. 3: An overview of the chemical digestion of the samples 


\section{Results}

Data were analyzed using descriptive statistics and inferential statistics. Descriptive statistics including tables for comparing the means amount of silver, arsenic, cadmium, cobalt, chromium, cesium, bismuth and barium in oak. Paliurusspina-christi and Phragmitesaustralis, according to PPM. In the inferential statistics for determining the normal distribution of silver, arsenic, cadmium, cobalt, chromium, cesium, bismuth and barium in terms of PPM, in oak plants, Paliurusspinachristi, Kolmogorov-Smirnov test and to determine the difference in silver content, Arsenic, cadmium, cobalt, chromium, cesium, bismuth and barium, according to PPM, one-way ANOVA has been used.

As it is seen, the calculated $\mathrm{Z}$ value for all of these metals in oak and Paliurusspina-christiplants is less than 1.96 and their level is less than 0.225 for two-domain tests. There is also a small distance between the mean and the middle, so we conclude that the distribution of these metals in the oak tree and Paliurusspinachristiplants is normal and parametric tests can be used. To study the hypothesis of this study, the amount of silver, arsenic, cadmium, cobalt, chromium, cesium, bismuth and barium in the PPM scale was measured in oak and Paliurusspina-christi. One-way analysis of variance was used to determine the difference between these metals in oak and Paliurusspina-christi.

From the values of "Table 2", since only $F$ is calculated for cadmium content $(F=123 / 4)$ with degrees of freedom $\mathrm{df}=17$ and $\mathrm{df}=2$ at $95 \%$ confidence level $(\alpha$ $=0.05$ ) from $\mathrm{F}$ criticality table $59 / 3 \mathrm{~F}=$ ), so we conclude that the difference between cadmium levels of oak and Paliurusspina-christi plants is statistically significant, but the means of other metals in the oak tree and Paliurusspina-christi plants is statistically equal to Is. Tukey's post hoc test was used to determine the means cadmium content in which oak and Paliurusspina-christi plants were more than others.

In Tukey's table "Table 4", the significance difference of each of the meanss with other meanss in the column houses is the difference between the mean with the * and in the columns of the P-value with a significant level less than 0.05 . From the values recorded in Table 4, only Paliurusspina-christi seedlings with oak tree have a significant difference $(\mathrm{P}$-value $=0.049)$ and it is evident from the mean of "Table 3" mean that the cadmium content of the Paliurusspina-christi It is more of an oak tree, in other words Paliurusspina-christi absorbs cadmium from other people better (Table 1).

Table 1: Means and Middle and Z-score Kolmogorov Smirnov and Significance Levels for Oak Tree and Paliurusspina-christi

\begin{tabular}{|c|c|c|c|c|c|c|}
\hline & Variable & Number & Means & Median & $\begin{array}{l}\text { Z kolmogorov } \\
\text { smirnov }\end{array}$ & $\begin{array}{l}\text { Significance } \\
\text { level }\end{array}$ \\
\hline \multirow[t]{8}{*}{ Oak } & Silver & 8 & 23.25 & 22.5 & 0.994 & 0.965 \\
\hline & Arsenic & 8 & 17.00 & 18.0 & 0.571 & 0.900 \\
\hline & Cadmium & 8 & 14.00 & 15.0 & 0.723 & 0.672 \\
\hline & Cobalt & 8 & 23.75 & 22.5 & 0.791 & 0.559 \\
\hline & Chrome & 8 & 21.25 & 21.0 & 0.458 & 0.985 \\
\hline & Cesium & 8 & 19.88 & 22.0 & 0.666 & 0.760 \\
\hline & Bismuth & 8 & 17.13 & 16.5 & 0.515 & 0.953 \\
\hline & Barium & 8 & 15.63 & 12.5 & 0.792 & 0.558 \\
\hline \multirow[t]{8}{*}{ Paliurusspina-christi } & silver & 8 & 26.75 & 25.0 & 0.494 & 0.966 \\
\hline & Arsenic & 8 & 18.25 & 20.0 & 0.756 & 0.618 \\
\hline & Cadmium & 8 & 20.88 & 20.0 & 0.542 & 0.931 \\
\hline & Cobalt & 8 & 26.00 & 27.5 & 0.684 & 0.738 \\
\hline & Chrome & 8 & 18.13 & 20.0 & 0.803 & 0.540 \\
\hline & Cesium & 8 & 23.50 & 23.5 & 0.417 & 0.995 \\
\hline & Bismuth & 8 & 15.88 & 15.0 & 0.758 & 0.613 \\
\hline & Barium & 8 & 12.50 & 15.0 & 0.863 & 0.446 \\
\hline \multirow[t]{8}{*}{ Phragmitesaustralis } & silver & 4 & 19.25 & 20.0 & 0.698 & 0.714 \\
\hline & Arsenic & 4 & 17.25 & 17.5 & 0.349 & 1.000 \\
\hline & Cadmium & 4 & 21.25 & 22.5 & 0.384 & 0.999 \\
\hline & Cobalt & 4 & 22.00 & 22.5 & 0.601 & 0.863 \\
\hline & Chrome & 4 & 17.50 & 15.0 & 0.883 & 0.417 \\
\hline & Cesium & 4 & 21.75 & 22.0 & 0.538 & 0.935 \\
\hline & Bismuth & 4 & 17.50 & 17.5 & 0.614 & 0.846 \\
\hline & Barium & 4 & 14.50 & 15.0 & 0.620 & 0.837 \\
\hline
\end{tabular}


Table 2: The results of one-way ANOVA test for the means amount of metal elements of silver, arsenic, cadmium, cobalt chromium, cesium, bismuth and barium in the oak tree and Paliurusspina-christi

\begin{tabular}{|c|c|c|c|c|c|c|}
\hline & & SS & df & MS & $\mathrm{F}$ & Significance level \\
\hline \multirow{2}{*}{ Silver } & Intergroup & 154.8000 & 2 & 77.400 & 0.65 & 0.535 \\
\hline & Within group & 2025.7500 & 17 & 119.162 & & \\
\hline \multirow[t]{2}{*}{ Arsenic } & Within group & 6.7000 & 2 & 3.350 & 0.124 & 0.884 \\
\hline & Within group & 458.2500 & 17 & 26.956 & & \\
\hline \multirow[t]{2}{*}{ Cadmium } & Within group & 235.5750 & 2 & 117.778 & 4.123 & 0.035 \\
\hline & Within group & 485.6250 & 17 & 28.566 & & \\
\hline \multirow[t]{2}{*}{ Cobalt } & Within group & 46.7000 & 2 & 23.350 & 0.808 & 0.462 \\
\hline & Within group & 491.5000 & 17 & 28.912 & & \\
\hline \multirow[t]{2}{*}{ Chrome } & Within group & $54,375.0000$ & 2 & 27.188 & 1.225 & 0.318 \\
\hline & Within group & 377.3750 & 17 & 22.199 & & \\
\hline \multirow[t]{2}{*}{ Cesium } & Within group & 52.5750 & 2 & 26.288 & 0.724 & 0.499 \\
\hline & Within group & 617.6250 & 17 & 36.331 & & \\
\hline \multirow[t]{2}{*}{ Bismuth } & Within group & 9.4500 & 2 & 4.725 & 0.336 & 0.719 \\
\hline & Within group & 238.7500 & 17 & 14.044 & & \\
\hline \multirow[t]{2}{*}{ Barium } & Within group & 27.6750 & 2 & 13.383 & 0.389 & 0.684 \\
\hline & Within group & 6.4 .875 & 17 & 35.581 & & \\
\hline
\end{tabular}

Table 3: Number, means and deviation of cadmium content of oak and Paliurusspina-christi plants

\begin{tabular}{llll}
\hline & Number & Means & sd \\
\hline Oak & 8 & 14.000 & 3.30 \\
Paliurusspina-christi & 8 & 20.875 & 5.22 \\
Phragmitesaustralis & 4 & 21.250 & 8.54 \\
\hline
\end{tabular}

Table 4: The results of Tukey's post hoc test to determine the significant difference of cadmium in samples

\begin{tabular}{llcl}
\hline Component & Componentj & Mean difference (i-j) & P-value \\
\hline Oak & Paliurusspina-christi & $-6.875^{*}$ & 0.049 \\
& Phragmitesaustralis & -7.25 & 0.097 \\
Paliurusspina-christi & Oak & $6.875^{*}$ & 0.049 \\
& Phragmitesaustralis & -0.375 & 0.993 \\
Phragmitesaustralis & Oak & 7.25 & 0.097 \\
& Paliurusspina-christi & 0.375 & 0.993 \\
\hline
\end{tabular}

*Note: The means cadmium content of the plant is higher than the others, but because the number and standard deviation of Phragmitesaustralis samples are very different, there is no significant difference in Tukey's test

\section{Discussion}

Many studies have been done on the role of cement plants on the environment and the development of air pollution and, consequently, its destructive effects on plants (Salama et al., 2011). The pollutants emitted from cement plants are often transmitted through the wind to the farther distances, depending on the severity of the wind at various distances from the plant on the soil, vegetation or residential areas of the area. Of course, the diffusion of these particles from the plant also depends on the size of the particles (Mandal and Voutchkov, 2011). As it was observed in the results, the cement plant is responsible for higher metals such as silver, arsenic, cadmium, cobalt and ... in cyanides. The presence of metals in dusty cement plants plays an important role in reducing the metabolic processes of plants. In addition, contamination from the cement plant contains amounts of toxic compounds such as fluoride, sulfuric acid, hydrochloric acid, lead, zinc, copper, manganese (Andrej, 1987). It is said that the canopy of trees is much better than other plant species that has the capability to absorb and absorb particles in the air, due to the fact that they have a more violent and rough surface in these plants (Manning and Feder, 1982). Increasing the concentrations of airborne dust reduces the photosynthesis capability in leaves, closes the leaf stomata and, in general, reduces the growth and fertility of the plants. Sadeghiravesh and Khorasani (2009) also found that there is a reverse correlation between diversity and density of vegetation with deposition of dust from dust from the cement plant. As the particle diffusion source fades away, the amount of deposition of particles decreases and the density and diversity of the coating increase.

\section{Conclusion}

Research on the effects of cement plant pollutants on vegetation around the cement plant has been shown to degrade plant life. As it was observed, the dust deposited on the leaves of three species of oak and Paliurusspina- 
christi and Phragmitesaustralis contained significant concentrations of such as silver, barium, bismuth, cesium, chromium, cobalt, cadmium and arsenic. The concentration of these elements in both species was reduced by distance from the factory. This means that the highest concentration of these elements was observed near the factory. The introduction of these compounds not only disrupts the metabolic activities of plants, but also can be the source of many dangerous diseases such as cancer for humans. Therefore, it is essential that factories located near residential centers should use appropriate filters to prevent the development of diseases such as cancer, respiratory problems and the disturbance of metabolic processes of plants and air pollution and the environment.

\section{Acknowledgement}

In the end, I must express my sincerest gratitude to all the colleagues and professors who co-operated in this research.

\section{Author's Contributions}

All authors equally contributed in this study.

\section{Ethics}

In this article, all ethical principles related to scientificresearch articles such as validity and authenticity, originality, data collection in a standard manner, integrity, the accuracy of research and etc were observed.

\section{References}

Abbasi, J., \& Salari, M. (2006). Environmental pollutants of Shahrood cement industries. Proceedings of the 5th Student festival on mining engineering. Iran, 18-31.

Adak, M. D., Adak, S., \& Purohit, K. M. (2007). Ambient air quality and health hazards near mini cement plants. Pollution Research, 26(3), 361.

Moopam, R. (1999). Manual of oceanographic observations and pollutant analysis methods. ROPME. Kuwait, 1, 20.

Andrej, J. (1987). Bees and their products as indicators of environmental pollution. Med. Weter, 43(6), 353-356.

Aydin, S., Aydin, S., Croteau, G., Sahin, Í., \& Citil, C. (2010). Ghrelin, nitrite and paraoxonase/arylesterase concentrations in cement plant workers. Journal of Medical Biochemistry, 29(2), 78-83.

Bertoldi, M., Borgini, A., Tittarelli, A., Fattore, E., Cau, A., Fanelli, R., \& Crosignani, P. (2012). Health effects for the population living near a cement plant: An epidemiological assessment. Environment international, 41, 1-7.
Daryanoosh, S. M., Goudarzi, G., Khaniabadi, Y. O., Armin, H., Bassiri, H., \& Khaniabadi, F. O. (2016). Effect of exposure to PM10 on cardiovascular diseases hospitalizations in Ahvaz, Khorramabad and Ilam, Iran during 2014. Iranian Journal of Health, Safety and Environment, 3(1), 428-433.

Environmental Protection Organization. (2003). Office of Legal and Parliamentary Affairs. Iranian Terms and Rules of Environmental Protection, 1st Edn., Tehran, Iran.

Amal, M. F., \& Migahid, M. M. (2011, February). Effect of cement-kiln dust pollution on the vegetation in the western Mediterranean desert of Egypt. In Proceedings of world academy of science, engineering and technology (Vol. 81, pp. 28-34).

Farmer, A. M. (1993). The effects of dust on vegetationa review. Environmental pollution, 79(1), 63-75.

Kakooei, H., Gholami, A., Ghasemkhani, M., Hosseini, M., Panahi, D., \& Pouryaghoub, G. (2012). Dust exposure and respiratory health effects in cement production. Acta Medica Iranica, 122-126.

Majnounian, H. (1990). Trees and the environment, Tehran, environmental protection agency. Environmental Education Office.

Mandal, A., \& Voutchkov, M. (2011). Heavy metals in soils around the cement factory in Rockfort, Kingston, Jamaica. International Journal of Geosciences, 2(1), 48.

Manning, W. J., \& Feder, W. A. (1980). Biomonitoring air pollutants with plants. Applied Science Publishers.

Migahid, M. M., \& Salama, M. (1995). Effect of cement dust on three halophytic species of the Mediterranean salt marshes in Egypt. Journal of Arid Environments, 30(3), 361-366.

Mishra, G. P. (1991). Impact of industrial pollution from a cement factory on water quality parameters at Kymore. Environment and ecology. Kalyani, 9(4), 876-880.

Mosavi, Z., Motassadi, S., Jozi, A., \& Khorasani, N. A. (2015). Investigating the effects of the dust from cement industry on vegetation diversity and density, case study: Shahroud cement industry. Journal of Health, 6(4), 429-38.

Nanos, G. D., \& Ilias, I. F. (2007). Effects of inert dust on olive (Olea europaea L.) leaf physiological parameters. Environmental Science and Pollution Research-International, 14(3), 212-214.

Princewill, C., \& Adanma, N. (2011). Metal concentration in soil and plants in abandoned cement factory. In International Conference on Biotechnology and Environment Management IPCBEE, Singapore (Vol. 18, pp. 146-150). 
Perez, P., \& Reyes, J. (2006). An integrated neural network model for PM10 forecasting. Atmospheric Environment, 40(16), 2845-2851.

Sadeghiravesh, M. K., \& Khorasani, N. (2009). Investigating the effects of dust on cement industry on vegetation diversity and density (Case study: Abyek Cement Factory). J. Environ. Sci. Techno., 11: 119-107. http://www.sid.ir/fa/journal/ViewPaper.aspx?id=1 11921
Salama, H. M., Al-Rumaih, M. M., \& Al-Dosary, M. A. (2011). Effects of Riyadh cement industry pollutions on some physiological and morphological factors of Datura innoxia Mill. plant. Saudi journal of biological sciences, 18(3), 227-237.

Singh, S. N., \& Rao, D. N. (1981). Certain responses of wheat plants to cement dust pollution. Environmental Pollution Series A, Ecological and Biological, 24(1), 75-81. 